\title{
Levels of Thyroid Hormones and Human Chorionic Gonadotropin in Normotensive Pregnant Women
}

\author{
${ }^{1}$ Akhilesh Kumar Singh, ${ }^{2}$ Prabhat Agrawal, ${ }^{3}$ Bechan Kumar Gautam, ${ }^{4}$ Ruchika Garg
}

\begin{abstract}
During pregnancy the hormonal changes take place, resulting in changes in thyroid functions. The present study was conducted to determine thyroid hormones and human chorionic gonadotropin (hCG) in normotensive pregnancy. Fifty normotensive pregnant subjects were included in the study. Age-matched 50 nonpregnant subjects, not having any disease were taken as control. Total triiodothyronine (total T3), total thyroxine (total T4), thyroid stimulating hormone (TSH), and hCG were estimated by using enzyme amplified chemiluminescent immunoassay. The level of thyroid hormones was found significantly increased in normotensive pregnant subjects as compared to that of control group. We therefore conclude that investigations should be done routinely in pregnancy.
\end{abstract}

Keywords: Human chorionic gonadotropin, Normotensive pregnancy, Triiodothyronine, Thyroxine.

How to cite this article: Singh AK, Agrawal P, Gautam BK, Garg R. Levels of Thyroid Hormones and Human Chorionic Gonadotropin in Normotensive Pregnant Women. J South Asian Feder Obst Gynae 2016;8(4):324-326.

Source of support: Nil

Conflict of interest: None

Date of received: 07 June 2016

Date of acceptance: 18 September 2016

Date of publication: October 2016

\section{INTRODUCTION}

Human chorionic gonadotropin (hCG) hormone synthesized by placenta is critical for implantation and maintenance of blastocyst. ${ }^{1}$ This hormone can stimulate the thyroid gland in the first trimester of pregnancy because of structural similarity with thyroid stimulating hormone (TSH). ${ }^{2}$ Thyroid hormones have an important role in embryogenesis and fetal development. ${ }^{3}$ That is why thyroid function is frequently assessed during pregnancy.

\footnotetext{
1,2,4 Assistant Professor, ${ }^{3}$ Junior Resident Doctor

${ }^{1-3}$ Department of Medicine, Sarojini Naidu Medical College Agra, Uttar Pradesh, India

${ }^{4}$ Department of Obstetrics and Gynecology, Sarojini Naidu Medical College, Agra, Uttar Pradesh, India

Corresponding Author: Bechan Kumar Gautam, Room No. 18 New P.G. Hostel, Sarojini Naidu Medical College, Agra, Uttar Pradesh, India, e-mail: gautambk07@gmail.com
}

\section{AIM}

The present study was undertaken:

- To determine hCG in women with normotensive pregnancy.

- To determine serum total circulating triiodothyronine (T3), total circulating thyroxine (T4), and TSH in women with normotensive pregnancy.

\section{MATERIALS AND METHODS}

This study was conducted at the Department of Medicine and Gynecology of Sarojini Naidu Medical College, Agra over a period of 12 months. All participants completed a medical history form and informed consent was taken in writing. All participants were also subjected to a questionnaire that included family income, maternal education and occupation, living, personal history like age, height, weight, dietary history, religion, addictions and medications, history of lactation, gravidity, gestation period, and previous laboratory investigations.

\section{Inclusion Criteria}

Fifty normotensive pregnant ladies were taken as subjects and 50 age-matched nonpregnant ladies were taken as controls.

\section{Exclusion Criteria}

Subjects with hypertension, proteinuria, edema, endocrine disease, renal disease, liver disease, human immunodeficiency virus infection were excluded from study.

\section{Sample Collection}

Venous blood sample from every patient and control was collected. After 2 hours of collection, the sample was centrifuged at 3,000 rpm for 5 minutes. Serum was separated and collected in a polythene tube with cork. Serum was immediately stored at $-202^{\circ}$ until assayed. The sera with no sign of hemolysis was used for analysis of hCG, total T3, total T4, and TSH.

Total T3 and T4 estimation was done by solid-phase competitive chemiluminescent enzyme immunoassay. ${ }^{4,5}$ Third-generation TSH and hCG concentrations were measured by solid-phase, two site chemiluminescent immunometric assay. ${ }^{6,7}$ 


\section{Statistical Analysis}

Numerical variables were reported in terms of mean and standard deviation. Statistical analysis of results was done by normal distribution $\mathrm{Z}$ test. In the analysis, variables showing $p$ value less than 0.05 and 0.001 were considered to be statistically significant and highly significant respectively.

\section{RESULTS}

Fifty normotensive pregnant subjects and 50 nonpregnant age-matched subjects were compared.

Table 1 showed the age of subjects ranging from 18 to 35 years. Majority of normotensive subjects were 21 to 30 years $(76 \%)$.

Table 2 showed level of hCG, total T3, total T4, and TSH in normotensive pregnant group and in healthy nonpregnant group .Study group showed a significantly higher $(\mathrm{p}<0.001)$ increase in hCG, total T3, total T4 while significant $(\mathrm{p}<0.05)$ increase in TSH as compared to levels of control subjects.

\section{DISCUSSION}

Table 3 showed that $24 \%$ of normotensive pregnant subjects had hypothyroidism, $4 \%$ had hyperthyroidism, and the remaining $72 \%$ of normotensive pregnant subjects were euthyroid.

In our study, the hCG levels in normotensive pregnant subjects showed highly significant rise of serum level

Table 1: Age-wise distribution of normotensive pregnant subjects

\begin{tabular}{lll}
\hline Age & No. of subjects $(n)$ & Percentage $(\%)$ \\
\hline $18-20$ years & 7 & 14 \\
21-25 years & 19 & 38 \\
26-30 years & 19 & 38 \\
31-35 years & 5 & 12 \\
\hline
\end{tabular}

Table 2: Hormonal profile in controls and normotensive pregnant subjects

\begin{tabular}{llll}
\hline Parameters & $\begin{array}{l}\text { Nonpregnant } \\
(n=50)\end{array}$ & $\begin{array}{l}\text { Normotensive } \\
\text { pregnant }(n=50)\end{array}$ & $p$-value \\
\hline hCG $(\mathrm{mlU} / \mathrm{mL})$ & $1.29 \pm 1.54$ & $17533 \pm 8919$ & 0.0001 \\
Total T3 $(\mathrm{ng} / \mathrm{dL})$ & $125 \pm 17.1$ & $162 \pm 51.7$ & 0.0001 \\
Total T4 $(\mu \mathrm{g} / \mathrm{dL})$ & $7.30 \pm 1.55$ & $11.5 \pm 3.83$ & 0.0001 \\
TSH $(\mu \mathrm{lU} / \mathrm{mL})$ & $3.29 \pm 0.54$ & $5.99 \pm 7.54$ & 0.0058 \\
\hline
\end{tabular}

Table 3: Distribution of normotensive pregnant subjects according to thyroid profile

\begin{tabular}{lll}
\hline Characteristics & \multicolumn{2}{c}{ Distribution of subjects, $n=50$ (100\%) } \\
\hline Hypothyroidism & 12 & $24 \%$ \\
Hyperthyroidism & 2 & $4 \%$ \\
Euthyroidism & 36 & $72 \%$ \\
\hline
\end{tabular}

of hCG $(\mathrm{p}<0.0001)$ when compared to that of controls. This hormone is a glycoprotein produced by developing placenta. This hormone is increased both in serum and urine as early as days after conception. ${ }^{8-11}$

Serum total T3 levels were significantly elevated $(p<0.001)$ in normotensive pregnant subjects. Zarghami et $\mathrm{al}^{12}$ studied thyroid function test in normal pregnant women as compared to nonpregnant women in Iran. This study showed that serum total T3 levels were normal in nonpregnant women, while in pregnant women the total T3 levels increased significantly. These findings are matching with our study.

Serum total T4 levels were significantly increased $(p<0.001)$ in normotensive pregnant subjects. The study conducted by Khandakar et $\mathrm{al}^{13}$ showed that serum total $\mathrm{T} 4$ levels of nonpregnant women were normal but in pregnant women the levels were significantly increased. Their findings are supporting our study.

In our study, the serum TSH level in normotensive pregnant subjects was significantly elevated as compared to nonpregnant group. Kumar et $\mathrm{al}^{14}$ showed progressive rise in TSH level throughout pregnancy, especially in third trimester. The findings in the study corroborate with our study.

In conclusion, these investigations should be done routinely during pregnancy, so that early diagnosis and treatment can prevent neurological impairment of fetal brain.

\section{REFERENCES}

1. Petraglia F, Volpe A, Gennazani AR, Rivier J, Sawchenko PE, Vale W. Neuroendocrinology of human placenta. Front Neuroendocrinol 1990;11:6-37.

2. Fantz CR, Dagogo-Jack S, Ladenson JH, Gronowski AM. Thyroid function during pregnancy. Clin Chem 1999 Dec;45(12):2250-2258.

3. Haddow JE, Palomaki GE, Allan WC, Williams JR, Knight GJ, Gagnon J, O'Heir CE, Mitchell ML, Hermos RJ, Waisbren $\mathrm{SE}$, et al. Maternal thyroid deficiency during pregnancy and subsequent neuropsychological development of the child. N Engl J Med 1999 Aug;341(8):549-555.

4. Utiger RD. Serum triiodothyronine in man. Ann Rev Med 1974;25:289-302.

5. Refetoff, S. Thyroid function tests. In: DeGroot, LJ, ed. Endocrinology. Philadelphia: Grune and Stratton; 1979.

6. Spencer CA, Takeuchi M, Kazarosyan M, MacKenzie F, Beckett GJ, Wilkinson E. Inter-laboratory/inter-method differences in functional sensitivity of immunometric assay of thyrotropin and impact on reliability of measurement of subnormal concentrations of thyrotropin. Clin Chem 1995 Mar;41(3):367-374.

7. Babson AL. The Immulite automated immunoassay system. J Clin Immunoassay 1991 Jun;14(2):83-88.

8. Batzer FR. Hormonal evaluation of early pregnancy. Fertil Steril 1980 Jul;34(1):1-13. 
9. Catt KJ, Dufau ML, Vaitukaitis JL. Appearance of hCG in pregnancy plasma following the initiation of implantation of the blastocyte. J Clin Endocrinol Metab 1975 Mar;40(3): 537-540.

10. Braunstein GD, Rasor J, Danzer H, Adler D, Wade ME. Serum human chorionic gonadotrophin levels throughout normal pregnancy. Am J Obstet Gynecol 1976 Nov;126(6): 678-681.

11. Lenton EA, Neal LM, Sulaiman R. Plasma concentration of human chorionic gonadotrophin from the time of implantation until the second week of pregnancy. Fertil Steril 1982 Jun;37(6):773-778

12. Zarghami N, Rohbani-Noubar M, Khosrowbeygi A. Thyroid hormones status during pregnancy in normal Iranian women. Indian J Clin Biochem 2005 Jul;20(2):182-185.

13. Khandakar MA, Ali MS, Kahtun M. Thyroid status of normal pregnant women in Dhaka City. Mymensingh Med J 2002 Jan;11(1):1-5.

14. Kumar A, Gupta N, Nath T, Sharma JB, Sharma S. Thyroid function tests in pregnancy. Ind J Med Sci 2003;57:252-258. 